\title{
Meningkatkan Mutu Kain Tenun Ikat Tradisional Di Desa/Kelurahan Roworena Secara Berkesinambungan Di Kabupaten Ende Dengan Pendekatan Metode TQM
}

\author{
Firmansyah $\mathbf{M}^{\mathbf{1}}$, Abraham Lomi ${ }^{2}$, Dhayal Gustopo ${ }^{3}$ \\ ${ }^{1)}$ Program Studi Teknik Industri S-1 Institut Teknologi Nasional Malang \\ ${ }^{2,3)}$ Program Studi Teknik Industri S-2, Institut Teknologi Nasional Malang \\ ${ }^{1)}$ Email: firmankid14@gmail.com
}

\begin{abstract}
Abstrak
Tenun ikat khas Ende adalah salah satu dari sekian banyak produk budaya tradisional khas Indonesia yang dibuat secara tradisional dan bernilai seni tinggi dan indah. Di kabupaten Ende terdapat salah satu desa / kelurahan, yaitu Desa Roworena, desa yang sebagian masyarakatnya menggantungkan penghasilan hidup mereka dengan menenun. Adanya Permasalahan yang terjadi pada industri kelompok tenun ikat adalah adanya penurunan mutu atau kecacatan pada kain tenun ikat yang disebabkan oleh berbagai faktor yang menyebabkan menurunnya keuntungan produk kain tenun ikat yang didapatkan pada kelompok industri kain tenun ikat itu sendiri. Dengan teori pendukung dalam penelitian ini adalah teori tentang kualitas, pengendalian kualitas, metode Fishbone (Tulang Ikan) dan Quality Control Circle (QCC) atau Gugus Kendali Mutu (GKM). Dari hasil penelitian di dapatkan 11 proses pembuatan kain tenun ikat yang belum berjalan dengan baik. Upaya peningkatan mutu kain tenun ikat dilakukan melalui perbaikan 11 tahapan proses pembuatan kain tenun ikat, di mana Dilakukan pengendalian kualitas berupa pengawasan pada setiap proses penenunan kain tenun ikat agar mendapatkan kualitas produk kain tenun ikat yang berkualitas. Selanjutnya dapat disimpulkan, Kelompok penenun kain tenun ikat melakukan pengendalian kualitas terhadap semua hal yang berkaitan dengan proses produksi. dari bahan baku yang digunakan dari proses bahan baku disiapkan seperti kapas, dan bahan pewarna sampai dengan proses penjahitan / penyatuan kain tenun ikat. Dari semua proses pembuatan kain tenun ikat itu perlu di kontrol dan dilakukan perbaikan secara terus menerus apabila terdapat kecacatan produk.
\end{abstract}

Kata kunci: tenun ikat, Fishbone, QCC, Ende

\section{Pendahuluan}

Kain tenun ikat khas Ende adalah salah satu dari sekian banyak produk budaya tradisional khas Indonesia yang dibuat secara tradisional dan bernilai seni tinggi dan indah. Proses pembuatan produk warisan budaya khas pulau di bagian timur Indonesia ini melewati sejumlah proses yang memakan waktu hingga berbulan-bulan. Dibutuhkan ketekunan dan kesabaran untuk menghasilkan sehelai kain tenun ikat dimana hampir semua proses pembuatan kain ikat tersebut dilakukan secara tradisional dan manual serta menuntut ketekunan dan kesabaran tinggi. Hal ini tentu menjadi salah satu tantangan bagi keberlangsungan produksi kain tenun ikat. Di kabupaten Ende terdapat salah satu desa / kelurahan, yaitu Desa Roworena, desa yang sebagian masyarakatnya menggantungkan penghasilan hidup mereka dengan menenun. Peningkatan mutu dalam bentuk motif, makna motif, serta sumber daya manusia, Di karenakan produk ini memang diciptakan dari proses manual dan berbeda dengan konsep 
industrilialisasi yang mengutamakan efektif, efisien, dan produktifitas. Sedangkan konsep peningkatan mutu tenun ikat ini mengutamakan kualitas mutu dan karakter kualitas tenun ikat. Dalam kehidupan sehari-hari seringkali kita mendengar orang membicarakan kualitas, misalnya mengenai kualitas sebagian besar produk dalam negeri. Konsep kualitas itu sendiri sering dianggap sebagai ukuran relatif kebaikan suatu produk dan jasa yang terdiri dari kualitas desain dan kualitas kesesuaian adalah suatu ukuran seberapa jauh suatu produk memenuhi persyaratan atau spesifikasi kualitas yang telah ditetapkan akan tetapi aspek ini bukanlah satu - satunya aspek kualitas.

Total Quality Management (TQM) merupakan suatu pendekatan dalam menjalankan usaha yang mencoba untuk memaksimumkan daya saing organisasi melalui perbaikan terus menerus atas produk, jasa, manusia, proses, dan lingkungannya. Adanya Permasalahan yang terjadi pada industri kelompok tenun ikat adalah adanya penurunan mutu atau kecacatan pada kain tenun ikat yang disebabkan oleh berbagai faktor yang menyebabkan menurunnya keuntungan produk kain tenun ikat yang didapatkan pada kelompok industri kain tenun ikat itu sendiri.Untuk mengatasi permasalahan di atas, perlunya suatu metode yang tepat untuk mencari akar permasalahan dari penyebab kecacatan untuk penurunan tingkat kecacatan produk pada industri usaha kelompok tenun ikat. Metode yang dapat digunakan untuk mengatasi kecacatan produk yaitu dengan mengidentifikasi alur proses kerja pembuatan kain tenun ikat dengan metode Diagram tulang ikan (Fishbone) adalah salah satu metode / tool di dalam meningkatkan kualitas. Diagram ini juga sering disebut dengan diagram sebab - akibat atau cause effect diagram. Penemunya adalah seorang ilmuwan jepang pada tahun 60-an. Bernama Dr. kouru Ishikawa. GKM (Gugus Kendali Mutu) adalah salah satu konsep baru untuk meningkatkan mutu dan produktivitas kerja Industri / jasa. Terbukti bahwa salah satu faktor keberhasilan industrialisasi di jepang adalah penerapan GKM secara efektif. Total Quality Qontrol (Pengendalian Mutu Terpadu) diprakarsai oleh Dr. J.M. Juran dan Dr. E.W. Deming dan dikembangkan di jepang oleh kaoru Ishikawa dengan menerapkan Quality Control Circle (QCC) atau Gugus Kendali Mutu.Gugus Kendali Mutu adalah sekelompok karyawan yang terdiri dari 3-8 orang dari unit kerja yang sama, yang dengan sukarela secara berkala dan berkesinambungan mengadakan pertemuan untuk melakukan kegiatan pengendalian mutu di tempat kerjanya dengan menggunakan alat kendali mutu dan proses pemecahan masalah.

\section{Rumusan Masalah}

Bagaimana memperbaiki dan meningkatkan mutu produk kain tenun ikat di desa / kelurahan Roworena menggunakan salah satu dari 7 Tools yang ada pada metode pendekatan TQM. dan menerapkan Quality Control Circle $(Q C C)$ atau Gugus Kendali Mutu.

\section{Tujuan Penelitian}

Memperbaiki mutu produk kain tenun ikat di desa / kelurahan Roworena dengan menggunakan salah satu dari 7 Tools yang ada pada metode pendekatan TQM dan menerapkan Quality Control Circle (QCC) atau Gugus Kendali Mutu.

\section{Manfaat Penelitian}

Manfaat yang diharapkan dari penelitian ini adalah mampu memperbaiki dan meningkatkan mutu kain tenun ikat Tradisional di Desa/Kelurahan Roworena Kabupaten Ende secara berkesinambungan.

\section{Batasan Penelitian}

Batasan - batasan Penelitian yang di gunakan meliputi:

1. Penelitian ini dilakukan pada kelompok tenun ikat di desa / kelurahan roworena kabupaten Ende Flores-NTT

2. Penelitian ini dilakukan selama 1 bulan 


\section{Metode Penelitian}

Dalam memecahkan masalah pada penelitian yang diamati, dibutuhkan langkah-langkah untuk menguraikan pendekatan dan model dari masalah tersebut. Langkah-langkah yang dilakukan adalah sebagai berikut:

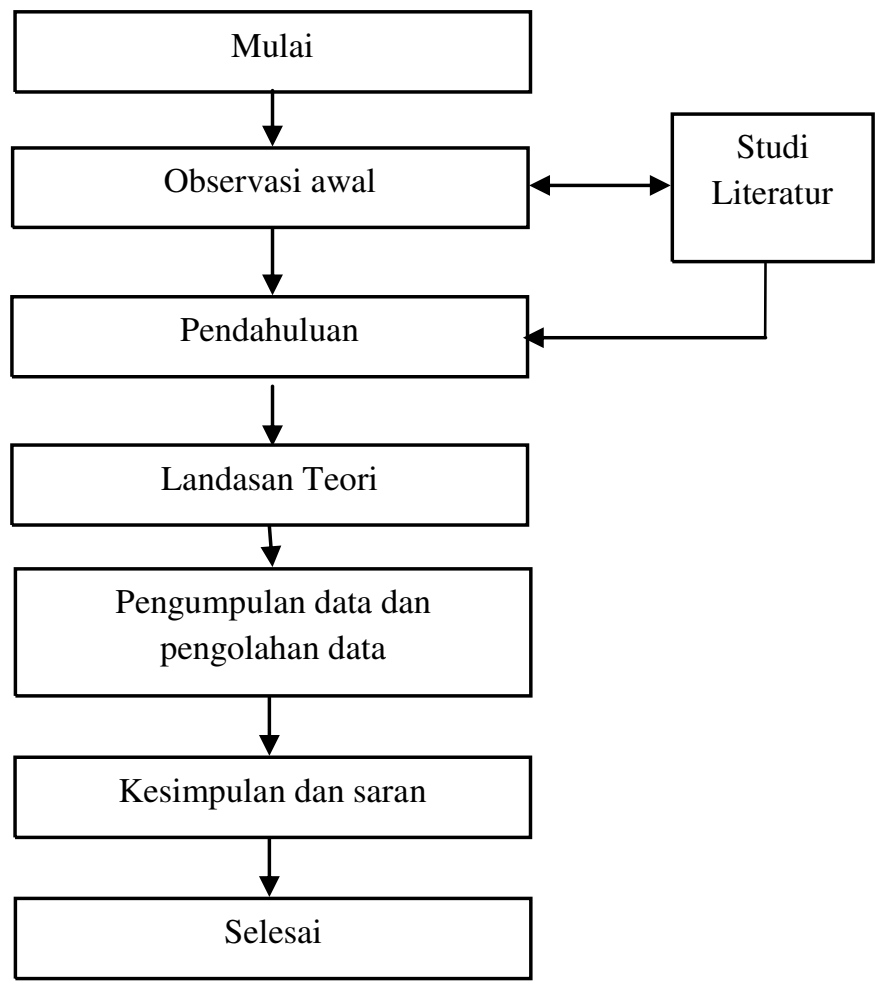

Gambar 1. Flow chart metodologi

Observasi Awal

Observasi awal adalah langkah pertama dalam melakukan penelitian ini Pada tahap ini dilakukan pengamatan pada Industri tenun untuk mengetahui proses kegiatan pembuatan kain tenun ikat dan mengetahui upaya pengendalian kualitas yang dilakukan.

Studi Literatur

Studi literatur dilakukan dengan tujuan mendapatkan konsep serta metode yang Berhubungan dengan masalah dan tujuan penelitian yang akan dicapai. Observasi awal dan studi literatur berjalan bersamaan dalam menyelesaikan permasalahan yang di angkat.

\section{Pendahuluan}

Pada tahap ini berisi tentang latar belakang masalah yang diangkat, perumusan masalah yang diangkat, tujuan penelitian berdasarkan perumusan masalah, batasan masalah, agar tidak menyimpang dari tujuan awal, manfaat penelitian, dan sistematika penulisan.

Landasan Teori

Pada tahap ini berisi tentang teori yang merupakan landasan teoritis yang akan menjadikerangka berpikir pelaksanaan penelitian ini. teori pendukung dalam penelitian ini adalah teori tentang kualitas, pengendalian kualitas, produk cacat, metode Fishbone (Tulang Ikan) dan Quality Control Circle (QCC) atau Gugus Kendali Mutu (GKM) 
Pengumpulan dan Pengolahan Data

Pada tahap ini dilakukan pengumpulan data yang diperlukan sebagai data yang akan digunakan untuk memecahkan masalah yang telah dirumuskan sebelumnya.

Kesimpulan dan Saran

Pada tahap ini dilakukan penarikan kesimpulan dari penelitian yang telah dilakukan, serta saran-saran untuk penelitian selanjutnya yang memiliki kaitan dengan penelitian ini, serta pihakpihak yang berkepentingan dalam upaya penurunan tingkat kecacatan produk terhadap proses kegiatan produksi.

\section{Hasil dan Pembahasan}

\section{Fish Bone (Cause and Effect)}

Jenis kegagalan pembuatan kain tenun ikat, bisa dilihat pada Fish bone Diagram atau Disebut juga sebagai diagram Ishikawa atau diagram tulang ikan:

Caus

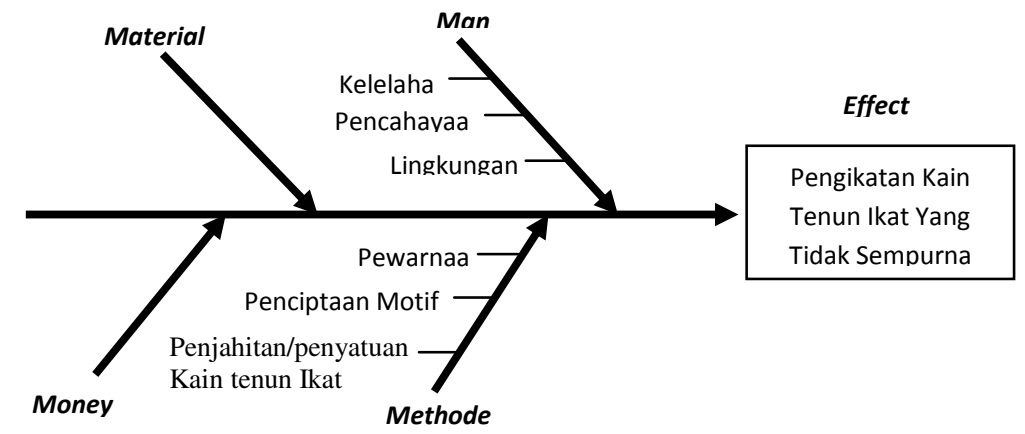

Gambar 2 Fishbone Diagram Kain Tenun Ikat

Dari gambar 2 diagram Fish Bone dapat di ketahui bahwa penyebab utama ke-cacatan dari Pengikatan kain tenun ikat dipengaruhi oleh faktor manusia (Man) dimana diduga antara lain dari faktor kelelahan, pencahayaan yang kurang sempurna ketika melakukan aktivitas menenun. Selain dari pada itu lingkungan juga berpengaruh pada aktivitas para penenun. Penyebab utama dari cacatnya kain tenun ikat, pewarnaan kain tenun ikat, Penciptaan motif, dan penjahitan / penyatuan kain tenun ikat. tetapi lebih dominan ke- cacatan kain tenun ikat terjadi pada proses penjahitan / penyatuan kain tenun ikat.

\section{a. Pembentukan GKM (Gugus Kendali Mutu)}

\section{GKM (Gugus Kendali Mutu)}

Kelompok yang terdiri dari 3-10 orang dari Kelompok penenun desa / kelurahan roworena, yang secara sukarela mengadakan pertemuan dengan teratur untuk menemukan, menganalisis, dan memecahkan permasalahan yang ada pada proses pembuatan kain tenun ikat.

2. Gugus Kendali Mutu kelompok tenun ikat desa / kelurahan Roworena

Setelah dilakukan pembentukan Gugus kendali mutu (GKM) dilakukan standarisasi perbaikan mutu kain tenun ikat karena memiliki ke-cacatan produk. standarisasi dari perbaikan mutu kain tenun ikat, dilakukan pada semua proses pembuatan kain tenun ikat. 


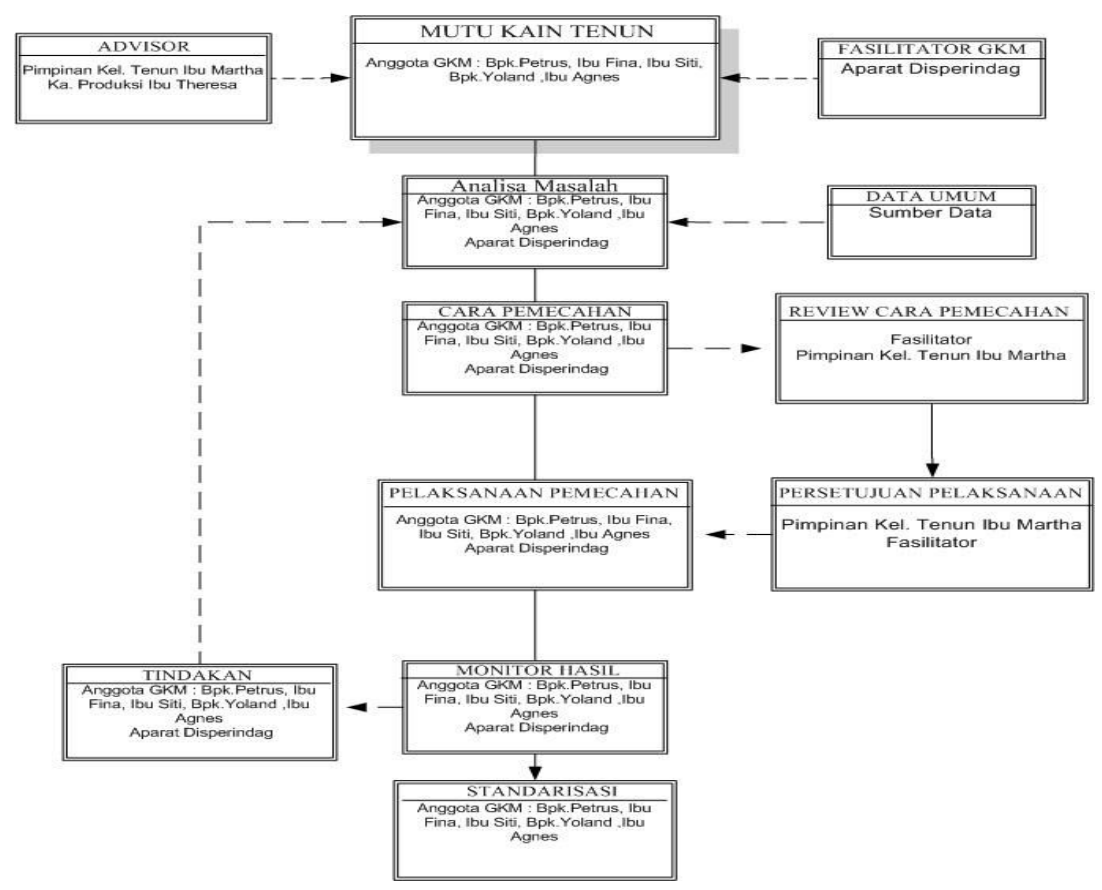

Gambar 3. Diagram Pembentukan GKM

Standarisasi proses pembuatan kain tenun ikat, adapun langkah-langkahnya sebagai berikut:

1. Langkah pertama, yang dilakukan penenun memisahkan kapas dan biji kapas secara manual dengan tangan kosong proses ini memakan waktu dan kapas yang di dapatkan juga belum tentu halus, namun di tahun 2014 muncul gagasan ide dari kelompok GKM, gagasan itu adalah menggunakan alat tradisional yang diberi nama "Ziku", dengan sedikit di modifikasi maka alat ini cukup membantu para pekerja tenun untuk melakukan proses pemisahan kapas dan biji kapas. Hasil yang dicapai pun, menunjukkan adanya perubahan. Dan hasil kapas yang didapat cukup baik dan memuaskan Pada proses ini dilakukan pengecekan dan pengawasan langsung oleh kepala Produksi kain tenun bersama team GKM yang secara langsung memonitoring proses ini.

2. Langkah kedua, pembuatan benang menggunakan alat ozo woe (alat penggulung benang), proses penggulungan benang menggunakan alat "ozo woe" sudah efektif, namun benang yang di hasilkan dalam seminggu hanya mendapatkan 6 gulung dalam seminggu, team GKM bersepakat melakukan perubahan pada proses ini, adapun perubahan yang dilakukan adalah team GKM melakukan penambahan alat "ozo woe" dan menambahkan jumlah pekerja pada proses ini, hasilnya benang yang dihasilkan dalam seminggu bertambah dari 6 gulung setiap minggunya kini bertambah menjadi 19 gulungan benang dalam seminggu. Pada proses ini di awasi langsung oleh team GKM yang telah diberi tugas untuk mengawasi para pekerja yang mengerjakan penggulungan benang.

3. Langkah ketiga, Pelurusan / peregang benang. pada proses ini sebelumnya, para penenun di desa roworena tidak memperhatikan benang yang akan digunakan untuk menenun. Sehingga benang yang akan digunakan untuk menenun tidak presisi. Gagasan atau ide dari team GKM adalah menggunakan alat "Dao denga" dimana alat tradisional ini digunakan para penenun lain di kabupaten yang berbeda, yang kemudian di modifikasi team GKM untuk digunakan oleh kelompok penenun dari desa roworena. dari Hasilnya benang yang diluruskan menjadi presisi. Proses diawasi oleh team dari GKM yang selalu memonitoring proses pengerjaannya.

4. Langkah keempat, pemintalan / penggulungan benang menggunakan alat tradisional (Suzo / ele wo'e), pada proses ini sebelumnya hanya dikerjakan oleh 4 orang pekerja, hasil yang didapat juga masih kurang dari target. Gagasan ide dari team GKM adalah penambahan para pekerja dan alat 
pada proses ini, pekerja di tambahkan 3-5 orang pekerja, sehingga mempercepat proses pemintalan / penggulungan benang. Hasil yang dicapai cukup signifikan dari tahun sebelumnya, dalam seminggu hasil pemintalan bertambah dari 6 benang yang didapat, ketika dilakukan penambahan pekerja dan alat benang hasil pintalan yang didapat dalam seminggu bertambah menjadi 19 benang hasil pemintalan. Pada proses ini selalu diawasi dan di monitoring oleh team GKM yang yang diberi tugas langsung untuk mengawasi.

5. Langkah kelima Penciptaan motif, pada tahun-tahun sebelumnya Proses Penciptaan motif bisa memakan waktu 3 minggu, dan proses ini dilakukan oleh 1 orang, hasil yang didapat tidak efisien. Karena waktu yang berminggu minggu yang dibutuhkan pada proses ini akan menghambat proses penenunan. Maka setelah dilakukan standarisasi berdasarkan ide dan gagasan team GKM, yaitu penambahan pekerja dari 1 orang ditambah menjadi 1-6 orang pada proses pewarnaan, terlihat perubahan yaitu, waktu yang memakan waktu 3 minggu pada proses pewarnaan dapat dikurangi menjadi 1-2 minggu. Team GKM juga melakukan perubahan yaitu penciptaan motif dengan mengikat motif menggunakan pucuk daun kelapa atau daun gebak. Karena sebelumnya Penenun terkadang menggunakan tali rafia sebagai alat pengikat motif yang hasilnya kurang efisien.

6. Langkah keenam, Persiapan bahan baku pewarna. Bahan dasar pewarna yang digunakan penenun kelompok tenun ikat desa Roworena pada kain tenun ikat, pada tahun sebelumnya masih menggunakan bahan baku pewarna buatan seperti wantex, kesumba dan bahan pewarna buatan lainnya. bahan pewarna buatan ini mempengaruhi mutu kain tenun ikat tradisional ende. Dari hasil diskusi team GKM menilai proses pewarnaan menggunakan bahan baku pewarna buatan tidak tahan lama pada kain tenun ikat dan Dari sisi harganya sendiri kain tenun ikat yang menggunakan bahan baku pewarna buatan akan mengurangi harga jual kain tenun ikat itu sendiri. Sehingga team GKM bersepakat melakukan perbaikan pada bahan baku yang digunakan sebagai pewarna. bahan baku pewarna yang di gunakan yaitu bahan baku pewarna alami, adapun bahan-bahan alami pewarna seperti seperti Taru, akar daun loba, kembo (akar mengkudu), daun nila, kapur sirih, kunyit, kulit nangka dan bahan alami lainnya. kain tenun ikat yang diberi pewarna alami lebih tahan lama, hasilnya kain tenun ikat semakin lama dan bertahun tahun disimpan maka warnanya akan semakin bagus. Pada persiapan bahan baku selalu di monitoring oleh team GKM agar tidak terjadi kesalahan pada saat menyiapkan bahan baku yang akan dipakai sebagai bahan baku pewarna kain tenun ikat.

7. Langkah ketujuh, pencelupan kain tenun ikat pada pewarna alami, metode yang digunakan pada saat pencelupan kain tenun ikat pada pewarna masih belum efisien, karena metode yang digunakan sebelumnya seperti pencelupan yang dilakukan hanya 1 kali pencelupan dirasa belum cukup oleh Team GKM, karena pewarna belum meresap secara merata dan tebal, hal ini dapat mengurangi kualitas kain tenun ikat tersebut. Hasil diskusi dan kesepakatan team GKM yaitu memperbaiki metode pencelupan yang sebelumnya hanya 1 kali pencelupan atau perendaman di tambah menjadi 3 kali pencelupan dan perendaman apabila hasil dari kain tenun ikat belum terang, sehingga pewarna melekat lebih tebal pada kain tenun Pada proses ini akan selalu diawasi oleh team GKM yang diberi tugas untuk memonitoring para penenun saat melakukan proses pencelupan atau perendaman kain tenun ikat pada pewarna alami.

8. Langkah kedelapan, metode penjemuran kain tenun ikat dilakukan selama 5 jam dimulai dari jam 2 siang s/d jam 6 sore dalam waktu 1 hari. Hasil kain tenun ikat yang didapat dari penjemuran ini dirasa belum cukup, gagasan dan ide dari team GKM yaitu memperbaiki metode penjemuran Agar warna kain tenun lebih mencolok dan benar-benar meresap dengan baik pada kain tenun dengan memperbaiki metode penjemuran yaitu kain tenun ikat yang sudah direndam pada pewarna di jemur selama 6 jam dimulai dari jam 12 siang s/d 5 sore selama 2 hari. Proses penjemuran rutin dipantau para penenun dan selalu di monitoring oleh team GKM. 
9. Langkah kesembilan, Penyusunan benang kain tenun berdasarkan motif, proses ini membutuhkan waktu yang cukup lama dan dikerjakan oleh 1 orang, sehingga proses penenunan menjadi terhambat. Namun Berdasarkan kesepakatan team GKM atas ide dan gagasannya maka dilakukan penambahan jumlah pekerja yang berjumlah 1-4 orang agar dapat mempercepat proses penyusunan motif, pada proses ini perlu diawasi dengan baik, maka team GKM menempatkan 2 orang untuk memonitoring proses penyusunan motif kain tenun ikat. Karena setiap Bagian-bagian helai benang tersebut tidak disusun secara acak ataupun sembarangan karena setiap helai benang memiliki nama dan jumlah yang berbeda. Nama-nama tersebut antara lain adalah sebagai berikut:

- Bue sebanyak 3 helai

- Gheko sebanyak 4 helai

- Wuzi sebanyak 3 helai

- Tekka sebanyak 5 helai

- Mata, sesuai dengan kebutuhan.

Mata adalah benang berwarna hitam yang digunakan sebagai pemisah untuk urutan atau komposisi berikutnya. Berikut ini adalah gambar dari komposisi pemisah atau urutan kain tenun ikat.

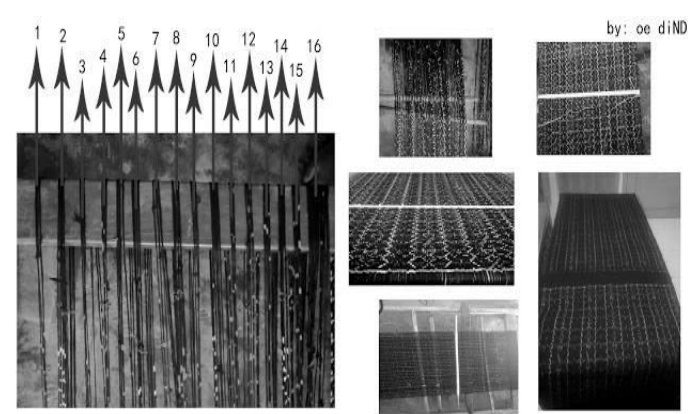

Gambar 4 komposisi atau pemisah kain

10.Langkah kesepuluh, Senda (Penenunan). Sebelum menenun persiapan alat harus disediakan terlebih dahulu seperti kabhe untuk menahan pinggang, bhoku seda yaitu tempat untuk menyimpan benang, kogo fungsinya penahan kain, ngewi untuk benang, gando untuk memasukan benang, kuku guru dan kuku rete untuk menahan benang agar tidak berceceran. setu ha'i fungsinya penahan kaki. Dalam pembuatan tenun ikat lamanya waktu tergantung dari jenis kain dan motif. Dalam proses pembuatan motif ini membutuhkan waktu minimal 4-6 bulan, dengan waktu 6 bulan dengan jumlah pekerja sebanyak 3 orang, produk yang dihasilkan hanya mendapat 2 kain tenun ikat. Gagasan dan ide team GKM yaitu memperbaiki metode penenunan dengan menambah jumlah pekerja dan alat penenun. dari 3 orang pekerja team GKM menambah 3-8 penenun, meskipun proses penenunan (Senda) memakan waktu 6 bulan tetapi produk atau hasil kain tenun ikat dapat bertambah jumlahnya produksinya. Team GKM juga menempatkan 2 orang untuk memonitoring proses penenunan.

11.Langkah kesebelas, Penjahitan / penyatuan kain tenun ikat. Proses Penjahitan / penyatuan kain tenun ikat menggunakan jarum jahit dan dijahit secara manual oleh penenun karena keterbatasan biaya, sehingga hasil proses penjahitan terkadang masih mengalami kecacatan produk. Namun dengan adanya ide dan gagasan team GKM bekerjasama dengan apparat Disperindag mengakomodasi penambahan alat berupa mesin jahit sebagai sarana penunjang aktivitas bekerja para kelompok penenun desa / kelurahan Roworena dan mengurangi tingkat kecacatan produk kain tenun ikat. Team GKM juga menempatkan 2 orang yang bertugas untuk selalu mengawasi dan memonitoring selama proses ini berlangsung. Team GKM juga tidak luput melakukan pengecekan secara berkala pada mesin jahit yang digunakan, seperti jarum jahit yang sudah tumpul atau aus dan performa mesin jahit yang digunakan.

Dari kesebelas langkah proses produksi kain tenun ikat, team GKM menempatkan beberapa orang dari team GKM untuk terus melakukan tugasnya untuk memantau dan memonitoring setiap langkah 
pengerjaan dari proses pembuatan kain tenun ikat. Hasil monitoring akan dicatat masing-masing pemantau dari setiap kelompok yang mempunyai tugas dari kesebelas proses di atas, yang kemudian akan melakukan evaluasi setiap minggunya secara bersama dengan penenun dan anggota team GKM untuk mengetahui kekurangan atau adanya kecacatan dari produk kain tenun ikat dari kesebelas proses yang dilakukan, sehingga team GKM dapat memperbaiki dan memperbaharui kesalahan yang terjadi secara berkesinambungan.

\section{a. Upaya Pengendalian Kualitas kerajinan kain tenun ikat}

Kelompok penenun kain tenun ikat melakukan pengendalian kualitas terhadap semua hal yang berkaitan dengan proses produksi. mulai dari bahan baku, kain tenun setengah jadi hingga kain tenun yang telah jadi. Dilakukan pengendalian kualitas berupa pengawasan pada setiap proses penenunan kain tenun ikat agar mendapatkan kualitas produk kain tenun ikat yang berkualitas. Pengamatan Mulai dari bahan baku yang digunakan dari proses bahan baku disiapkan seperti kapas, dan bahan pewarna sampai dengan proses penjahitan / penyatuan kain tenun ikat.

Tahapan-tahapan melakukan implementasi perbaikan

a. Implementasi Manajemen

Implementasi perbaikan pada manajemen Tenun Ikat dengan memberikan konsep kualitas yang secara jelas disampaikan melalui komitmen kelompok Tenun ikat tentang pentingnya kualitas. Kualitas merupakan ukuran yang digunakan oleh konsumen dalam mengkonsumsi produk. Dengan demikian kelompok tenun ikat di desa / kelurahan Roworena kab. Ende telah dibiasakan untuk menghasilkan tenun yang berkualitas bagi konsumennya.

\section{b. Penunjang Implementasi}

Proses penunjang dalam implementasi perbaikan dalam Total Quality Management berfokus pada obsesi terhadap mutu, pendekatan ilmiah dalam merancang keputusan dan proses pekerjaan, komitmen jangka panjang, kerja sama tim, perbaikan sistem secara berkesinambungan, serta pendidikan dan pelatihan. Dalam hal ini, Industri kelompok tenun ikat desa / kelurahan Roworena harus mewujudkan pelayanan yang bertujuan utama untuk memenuhi kebutuhan dan keinginan masyarakat. Dengan adanya obsesi ini, motivasi kerja pengrajin tenun ikat akan meningkat. Kerja sama tim (Team Building) yang kuat juga turut menentukan keberhasilan para kelompok pengrajin tenun ikat desa / kelurahan Roworena Hal ini yang menunjang adanya keberhasilan implementasi perbaikan mutu kain tenun ikat, mulai dari proses persiapan bahan baku sampai dengan proses penenunan. Dari semua proses pembuatan kain tenun ikat itu perlu di kontrol dan dilakukan perbaikan secara terus menerus apabila terdapat kecacatan produk. Hal terakhir yang perlu untuk diterapkan di industri kelompok tenun ikat desa / kelurahan Roworena yaitu Pendidikan dan pelatihan bagi para pengrajin tenun ikat, ini merupakan upaya untuk memaksimalkan kinerja secara personal. Dengan dilakukannya pendidikan dan pelatihan akan membawa peningkatan mutu kerja dan mengembangkan keahlian serta pengetahuan agar pekerjaan dapat diselesaikan dengan cepat efektif sehingga dapat menekan presentase jumlah kecacatan produk yang terjadi.

c. Mengatasi Penghambat Implementasi

Langkah yang dapat dilakukan dalam mengatasi penghambat implementasi berdasarkan Total Quality Manajement adalah :

1. Komitmen dari manajemen

Dengan dibentuknya GKM (Gugus Kendali Mutu) maka dapat dikatakan pengrajin kain tenun ikat di desa / kelurahan Roworena sudah memiliki komitmen untuk melakukan perbaikan mutu secara berkelanjutan secara terus menerus. Komitmen dari team GKM yaitu dengan melakukan standarisasi pada proses pembuatan kain tenun ikat, mengadakan pendidikan dan pelatihan kepada pengrajin tenun akan pentingnya kualitas, serta bekerja sama dengan lembaga-lembaga tingkat kabupaten yang ada di ende menanamkan unsur-unsur budaya dan pelestarian kain tenun ikat kepada generasi muda khususnya yang ada di kabupaten Ende. Manajemen dari Team GKM juga akan bekerja sama dengan disperindag 
kab. Ende untuk mempublikasikan serta memperluas segmen pasarnya sampai kemancanegara, dan menciptakan produk baru yang tidak terlepas dari motif khas Endenya.

\section{Kesimpulan}

Upaya peningkatan mutu kain tenun ikat dilakukan melalui beberapa tahapan. Tahapan tersebut adalah Pertama yang harus dilakukan adalah dengan menggunakan alat tradisional yang diberi nama "Ziku", sebagai alat pemisah kapas dan biji kapas. Selanjutnya langkah kedua adalah pembuatan benang menggunakan alat "ozo woe" (alat penggulung benang), Setelah itu melakukan tahap ketiga adalah Pelurusan/peregang benang. menggunakan alat "Dao denga" Masuk ke tahap keempat yaitu, pemintalan/penggulungan benang menggunakan alat tradisional (Suzo / ele wo'e). Dan setelah itu adalah langkah kelima Penciptaan motif, yaitu penambahan pekerja dari 1 orang ditambah menjadi 1-6 orang pada proses pewarnaan. Langkah yang keenam adalah, Persiapan bahan baku pewarna. adapun bahan-bahan alami pewarna seperti seperti Taru, akar daun loba, kembo (akar mengkudu), daun nila, kapur sirih, kunyit, kulit nangka dan bahan alami lainnya. Dan langkah ketujuh adalah, pencelupan kain tenun ikat pada pewarna alami, pencelupan atau perendaman di tambah menjadi 3 kali pencelupan dan perendaman apabila hasil dari kain tenun ikat belum terang. Dan langkah kedelapan, metode penjemuran kain tenun ikat, kain tenun ikat dijemur selama 6 jam dimulai dari jam 12 siang s/d 5 sore selama 2 hari. Hampir selesai dan setelah itu adalah langkah kesembilan, Penyusunan benang kain tenun berdasarkan motif, dilakukan penambahan jumlah pekerja yang berjumlah 1-4 orang agar dapat mempercepat proses penyusunan motif. Langkah kesepuluh adalah, Senda (Penenunan). menambah jumlah pekerja dan alat penenun. Dan langkah terakhir adalah langkah kesebelas, Penjahitan / penyatuan kain tenun ikat. penambahan alat berupa mesin jahit sebagai sarana penunjang aktivitas bekerja para kelompok penenun desa / kelurahan Roworena dan mengurangi tingkat kecacatan produk kain tenun ikat.

\section{Daftar Referensi}

[1] Jay Heizer, Barry Render,2013. International Edition "Operations Management", Sixth Edition

[2] Ikat From Flores Island Diane Gaffney Journal for Weavers, Spinners and Dyers 248, Winter.

[3] Levine, Ronda. Theories in Total Quality Management. Online; http://www.brighthub.com/office/project-management/articles/72443.aspx (Diakses,Tanggal 19 juli,2014).

[4] Deming, Edward. A System of Profound Knowledge. Washington DC: Pearson 1990, h. 22.

[5] Disraeli, Benjamin. Deming's 14 Points for Management. Online: http: // www. stat. auckland. ac. $\mathrm{Nz} / \sim$ mullins / quality /Deming.pdf (Diakses Tanggal 14 juli, 2014).

[6] Lee, Thomas H and Tobby, Woll,1995. "Creating the New Center For Quality Of Management", The Center For Quality Management Journal, Cambridge.

[7] Soewarso Hardjosoedarmo, Fellow of the world Academy of Quality and Productivity Science,Edisi Revisi

[8] Fandy Tjiptono \& Anastasia Diana,"Total Quality Management", Edisi Revisi

[9] Desai,K., Desai, M.S., \& Eason,M.K. 2009. Teaching Ishikawa's "Fisbhone" as Planning Tool. Academy of Educational Leadership Journal,13(1),19-35 